\title{
Development of Saxitoxin-Sensitive and Insensitive Sodium Channels in Cultured Neonatal Rat Astrocytes
}

\author{
Paul J. Yarowsky ${ }^{1}$ and Bruce K. Krueger ${ }^{2}$ \\ Departments of 'Pharmacology and Experimental Therapeutics and ${ }^{2}$ Physiology, University of Maryland School of \\ Medicine, Baltimore, Maryland 21201
}

\begin{abstract}
Voltage-sensitive Na channels were studied in cultures of neonatal rat cortical astrocytes. These channels were present at all times in culture as determined by tracer ${ }^{22} \mathrm{Na}^{+}$influx in the presence of batrachotoxin (BTX) and sea anemone polypeptide toxin (AxTX). The affinity of saxitoxin (STX) binding and sensitivity to STX inhibition of sodium influx were utilized to characterize these channels. Up to $7 \mathrm{~d}$ in culture, high-affinity ${ }^{3} \mathrm{H}-\mathrm{STX}$ binding $\left(\mathrm{K}_{\mathrm{d}}\right.$ of $0.2 \mathrm{nM}$ at $4^{\circ} \mathrm{C}$ ) was very low, and ${ }^{22} \mathrm{Na}^{+}$influx was inhibited only by high concentrations $\left(K_{i}=170 \mathrm{nM}\right)$ of STX. From 7 to $14 \mathrm{~d}$, total speciflc binding of STX increased to a maximum of over $2 \mathrm{pmol} / \mathrm{mg}$ protein and remained constant for $28 \mathrm{~d}$. By $14 \mathrm{~d}$, inhibition of ${ }^{22} \mathrm{Na}^{+}$influx by STX was clearly biphasic, indicating the presence of 2 populations of channels with $K_{i}^{\prime}$ 's of $0.2 \mathrm{~nm}$ and $150 \mathrm{~nm}$. At $14 \mathrm{~d}$ in culture, binding of ${ }^{3} \mathrm{H}-\mathrm{STX}$ to astrocyte membranes revealed the presence of 2 specific sites. During this second week, increasing numbers of high-affinity STX binding sites and increasing sensitivity to the inhibition of BTX + AxTX-stimulated ${ }^{22} \mathrm{Na}^{+}$influx by STX coincided with the change in morphology of primitive flat polygonal cells to highly branched stellate forms characteristic of mature astrocytes in vivo. Changes in culture conditions modified the time course of the onset of high STX affinity binding. Twentyfour hours after changing to serum-free G5 medium, there was both an 8-fold increase in STX binding sites and a change to a stellate shape in all cells. The results suggest that although low-affinity STX Na channels are always present in astrocytes, after $7 \mathrm{~d}$ in culture a different population of channels appears with the high affinity for STX characteristic of adult neuronal sodium channels. This spontaneous process is greatly accelerated by changing to a chemically defined medium.
\end{abstract}

Although voltage-sensitive ion channels are essential for the generation and propagation of action potentials and the release of neurotransmitters in neuronal cells, their presence and activity generally have not been considered to be a property of astroyctes in the mammalian CNS. Recently, however, several

Received June 13, 1988; revised Aug. 3, 1988; accepted Aug. 4, 1988.

This work was supported by NSF grant BNS 8711829 (P.J.Y.), NIH grant NS16285 (B.K.K.) and U.S. Army M.R.D.C. contract DAMD 17-85-C5283 (B.K.K.). We thank R. Johnson, W. C. Zinkand, D. Brougher, and C. Kabacoff for excellent technical assistance and Drs. R. J. Bloch, D. B. Burt, and M. B. Clark for comments on the manuscript.

Correspondence should be addressed to Dr. Paul. J. Yarowsky, Department of Pharmacology and Experimental Therapeutics, University of Maryland School of Medicine, 660 West Redwood Street, Baltimore, MD 21201.

Copyright @ 1989 Society for Neuroscience $0270-6474 / 89 / 031055-07 \$ 02.00 / 0$ reports of voltage-sensitive ion channels in astrocytes have appeared, and voltage-dependent calcium, chloride, potassium, and sodium currents have becn described (Bcvan ct al., 1985; Gray and Ritchie, 1986; Quandt and MacVicar, 1986; Nowak et al., 1987; Barres et al., 1988). Of these, the voltage-sensitive sodium channel has been of special interest because its presence would not have been anticipated in cells thought to be electrically silent.

In primary cultures of rat astrocytes, Bowman et al. (1984) showed that cells were depolarized by the sodium channel toxins veratridine and scorpion toxin $(\mathrm{ScTx})$. This depolarization was blocked by 16 nM tetrodotoxin (TTX). Whole-cell patch-clamp recordings and single-channel recordings in both cell-free or attached patches revealed the existence of a voltage-gated $\mathrm{Na}$ current (Bevan et al., 1985; Nowak et al., 1987; Barres et al., 1988). Bevan et al. reported low TTX sensitivity of whole-cell $\mathrm{Na}$ current, with $520 \mathrm{~nm}$ TTX required to block half the Na current at $20^{\circ} \mathrm{C}$ but found high-affinity ${ }^{3} \mathrm{H}$-saxitoxin (STX) binding $\left(K_{d}\right.$ of $2 \mathrm{~nm}$ at $\left.4^{\circ} \mathrm{C}\right)$. These findings suggest that 2 types of sodium channel might exist in astrocytes, one of high and another of low affinity for STX, but their proportions and the factors that control their expression have not been described.

Biochemical studies of voltage-sensitive sodium channels in other preparations have been facilitated by the use of a number of toxins that bind with high affinity and specificity to sites on the $\mathrm{Na}$ channel protein and alter its properties. These toxins have been classified into several groups (Catterall, 1986). Heterocyclic guanidinium toxins such as STX and TTX bind near the channel pore and inhibit ion transport (site 1). Liposoluble steroidal alkaloid toxins such as batrachotoxin (BTX) and veratridine bind at site 2 and cause persistent activation of voltagedependent sodium permeability and slowing of inactivation. Polypeptide toxins such as a sea anemone toxin (AxTx) and scorpion venom toxin (ScTx) slow inactivation (site 3) and enhance persistant activation by the alkaloid toxins.

Using astrocytes with $\mathrm{Na}$ channels activated by toxins acting at sites 2 and 3, we have investigated the sensitivity to STX. Parallel experiments were carried out with ${ }^{3} \mathrm{H}-\mathrm{STX}$ binding (Ritchie and Rogart, 1977). We find that there are 2 types of sodium channels based on different affinities for STX. These channels appear at different times in culture; a low-affinity STX channel is present at all times up to 4 weeks in culture, and a highaffinity STX channel appears after 1 week in culture.

\section{Materials and Methods}

Materials. ${ }^{3} \mathrm{H}-\mathrm{STX}$ was purchased from Amersham, Arlington Heights, IL. STX was provided by J. E. Gilchrist, FDA, Cincinnati, OH. Sea anemone polypeptide neurotoxin from Anthropleura xanthogrammica 
(AxTx) was prepared as described by Norton et al. (1976). Fibroblast growth factor was from Collaborative Research. BTX was a generous gift of Dr. John Daly, National Institutes of Health, Bethesda, MD. Cow anti-rabbit GFAP was purchased from Dako, Santa Barbara, CA. Monoclonal anti GalC IgG3, described and characterized by Ranscht et al. (1982), was a generous gift from Dr. Patrick Wood, Washington University, St. Louis, MO. Anti-neurofilament antibody was a gift from Dr. Paul Fishman, University of Maryland Medical School. All other items were obtained from Sigma.

Astrocyte cultures. Primary astrocyte cell cultures were prepared using a modification of the procedure of Booher and Sensenbrenner (1972). Cerebral hemispheres of newborn rats $(<1-\mathrm{d}$-old) were removed, placed in medium (modified MEM) with $20 \%$ fetal calf serum, cleaned of meninges, and trimmed to retain the neopallium. The tissue was then minced into small $\left(1 \mathrm{~mm}^{3}\right)$ pieces, transferred to a $50-\mathrm{ml}$ round-bottomed tube, and then mechanically disrupted by vortexing $(75 \mathrm{sec})$. This technique destroys most of the neurons and allows the small, immature, proliferative cells to survive. The cell suspension was then filtered through sterile nylon screening cloth with pore sizes of $80 \mu \mathrm{m}$ (first sieving) and $10 \mu \mathrm{m}$ (second sieving) to remove blood vessels and aggregated cells. The cell suspension was not digested with enzymes. The volume of the filtered cell suspension (now enriched in astrocyte precursors) was then adjusted with MEM ( $9 \mathrm{ml}$ per brain) containing $15 \%$ fetal calf serum at a plating density of $2-3 \times 10^{6}$ cells $/ 35-\mathrm{mm}$ dish and seeded in uncoated plastic culture dishes $(35 \mathrm{~mm})$. The yield was usually 9 dishes per brain. In some experiments this medium was replaced with serumfree G5 medium at day 7 (see below).

Chemically defined medium. Recent reports have described several types of chemically defined media that support the survival of astrocytes (Morrison and de Vellis, 1984; Bottenstein, 1985). We used the medium described by Bottenstein (G5). It consists of Dulbecco's modified Eagle's medium mixed 1:1 with Ham's F-12 and supplemented with $5 \mathrm{ng} / \mathrm{ml}$ biotin, $10 \mathrm{~nm}$ hydrocortisone, $30 \mathrm{~nm}$ selenium, $50 \mu \mathrm{g} / \mathrm{ml}$ transferrin, 5 $\mu \mathrm{g} / \mathrm{ml}$ insulin, $10 \mathrm{ng} / \mathrm{ml}$ fibroblast growth factor and $10 \mathrm{ng} / \mathrm{ml}$ epidermal growth factor.

STX binding to whole cells. The ability of STX to bind (Ritchie and Rogart, 1977) to cultured cells was determined with ${ }^{3} \mathrm{H}-\mathrm{STX}$ (specific activity $30-68 \mathrm{Ci} / \mathrm{mmol}$; purity $60-88 \%$; Amersham). The cells were washed in binding medium containing $130 \mathrm{~mm}$ choline chloride $(\mathrm{ChCl})$, $1.8 \mathrm{~mm} \mathrm{CaCl}_{2}, 5.4 \mathrm{~mm} \mathrm{KCl}, 0.8 \mathrm{~mm} \mathrm{MgSO}_{4}, 4.5 \mathrm{~mm}$ glucose, and 50 mM HEPES (pH 7.4 with Tris base) and equilibrated for $60 \mathrm{~min}$ at $4^{\circ} \mathrm{C}$. They were then exposed for $60 \mathrm{~min}$ at $4^{\circ} \mathrm{C}$ to various concentrations of ${ }^{3} \mathrm{H}$-STX in the presence or absence of $5 \mu \mathrm{M}$ cold STX. The latter concentration was sufficient to completely inhibit the saturable binding of ${ }^{3} \mathrm{H}-\mathrm{STX}$ by both high- and low-affinity components. Unbound radioactivity was removed by rapidly washing the cultures 4 times with medium containing $160 \mathrm{~mm} \mathrm{ChCl}$ in $50 \mathrm{~mm}$ HEPES (pH 7.4). The cultures were then lysed with $1 \mathrm{ml} 0.1 \mathrm{~N} \mathrm{NaOH}$ and counted by liquid scintillation spectroscopy. The difference between total binding and nonspecific binding was defined as the specific binding. Specific binding was determined in quadruplicate and is expressed per milligram of protein as determined by the method of Pierce and Suelter (1977).

$S T X$ binding to glial membrane preparation. Astrocyte membranes were prepared from cells grown in primary cultures by the method of Shea et al. (1986). Cells were rinsed with ice-cold PBS and scraped from the dish in $1 \mathrm{ml}$ of $50 \mathrm{~mm}$ Tris- $\mathrm{HCl}(\mathrm{pH} \mathrm{6.8)}$ containing $5 \mathrm{~mm}$ EGTA and aprotinin (0.026 units). The cells were homogenized for $15 \mathrm{sec}$ using an Ultra-Turrax (Tekmar Co., Cincinnati, $\mathrm{OH}$ ) homogenizer, and the suspension was centrifuged at $1000 \times g$ for $15 \mathrm{~min}$. The supernatant (S1) was gently aspirated and saved, and the pellet was resuspended in $0.32 \mathrm{M}$ sucrose and centrifuged again at $1000 \times g$ for $15 \mathrm{~min}$. The resulting pellet (P1) was saved and the supernatant pooled with the S1 from the first spin. The combined supernatant $\mathrm{S} 1$ was centrifuged at $10,000 \times g$ for $20 \mathrm{~min}$, and the pellet (P2) was saved. The S2 supernatant was then centrifuged at $100,000 \times g$ for $30 \mathrm{~min}$. The pellet (P3) was resuspended in $0.4 \mathrm{M}$ sucrose and frozen until it was used for binding assays.

The binding of ${ }^{3} \mathrm{H}$-STX to astrocyte membranes was determined by filtration on glass fiber filters (Krueger et al., 1979). The astroglial membrane preparation was diluted $1: 10$ to $1: 20$ in a high-salt solution of $135 \mathrm{~mm} \mathrm{ChCl}+20 \mathrm{~mm}$ HEPES, pH 7.4. Membrane fractions $(0.01-$ $0.06 \mathrm{mg}$ protein) were incubated for $30 \mathrm{~min}$ at $0^{\circ} \mathrm{C}$ in the presence of various concentrations of ${ }^{3} \mathrm{H}-\mathrm{STX}$ and $135 \mathrm{~mm} \mathrm{ChCl,} 20 \mathrm{~mm}$ HEPES, $\mathrm{pH}$ 7.4. Excess unlabeled STX $(5 \mu \mathrm{M})$ was also used in some samples for determining nonspecific binding. Samples were rapidly filtered over glass fiber filters (type 25, Schleicher and Schuell, Keene, NH) under vacuum and were washed with $10 \mathrm{ml}$ of ice-cold $135 \mathrm{~mm} \mathrm{ChCl,} 20 \mathrm{~mm}$ HEPES, pH 7.4. The filters were counted by liquid scintillation spectroscopy, and the amount of specifically bound STX was calculated from the radioactivity retained on the filters after subtraction of nonspecific binding.

Measurement of sodium flux. The results of Catterall (1981) suggested that at low sodium concentrations, the rate of sodium entry is proportional to the external sodium concentrations and appears to be directly proportional to the number of sodium channels in the cell. We therefore conducted all measurements in low $\mathrm{Na}^{+}$medium. Thus, cells were washed twice in $\mathrm{Na}^{+}$-free medium, a choline-substituted $\mathrm{Na}^{+}$-free medium preincubated in $1 \mu \mathrm{M}$ BTX and $100 \mathrm{~nm}$ polypeptide neurotoxin AxTx for $30 \mathrm{~min}$ at $35^{\circ} \mathrm{C}$ to ensure equilibrium binding. After the preincubation pcriod was complcted, the $\mathrm{Na}^{+}$influx was mcasurcd in low $\mathrm{Na}^{+}$ medium [120 mM ChCl, 5.4 mM KCl, $10 \mathrm{~mm} \mathrm{NaCl}, 1.8 \mathrm{~mm} \mathrm{CaCl}_{2}, 0.8$ $\mathrm{mM} \mathrm{MgSO}_{4}, 5 \mathrm{~mm}$ glucose, and $50 \mathrm{~mm}$ HEPES (pH adjusted to 7.4)] that contained ${ }^{22} \mathrm{Na}^{+}(2.0-2.5 \mu \mathrm{Ci} / \mathrm{ml})$ at $34^{\circ} \mathrm{C}$. It was not necessary to include the toxins in the incubation solution since no difference was found in cells incubated with or without the toxins (cf. Sherman et al., 1983). The medium was removed and the cultures were rapidly washed 6 times with $1 \mathrm{ml}$ of $\mathrm{Na}^{+}$-free medium $(163 \mathrm{~mm} \mathrm{ChCl}, 1.8 \mathrm{mM} \mathrm{CaCl}$, $50 \mathrm{~mm}$ HEPES, $\mathrm{pH} \mathrm{7.4)}$ at $4^{\circ} \mathrm{C}$. The total time required for the rinses was less than $25 \mathrm{sec}$. Cells were dissolved in $1 \mathrm{ml}$ of $0.1 \mathrm{~N} \mathrm{NaOH}$, and the residual radioactivity was measured with a gamma counter. All uptakes were determined in quadruplicate and expressed per milligram protein. The time dependence of ${ }^{22} \mathrm{Na}^{+}$influx showed that it was linear to $30 \mathrm{sec}$. Before $6 \mathrm{~d}$ in culture, cells were not fully attached and cellular debris was still present. This made ${ }^{22} \mathrm{Na}^{+}$flux measurements quite variable at these early times.

Immunocytochemistry. Glial fibrillary acid protein (GFAP) was used as an astrocyte marker, neurofilament as a neuronal marker, and galactocerebroside (GC) as an oligodendrocyte marker. All cells were grown on glass coverslips for identification by these cell-specific markers.

For GFAP localization, cells were first washed $3 \times$ in PBS, fixed in cold acetone $\left(-10^{\circ} \mathrm{C}\right)$ for $5 \mathrm{~min}$, and rinsed $3 \times$ in PBS. The coverslips were then placed in a humidified environment, and a 1:500 dilution of rabbit antiserum directed against cow GFAP in $1 \%$ normal goat serum (PBS-NS) was applied to the cell monolayer for $2 \mathrm{hr}$ at room temperature. The cells were again washed $6 \times$ in PBS and then incubated for $30 \mathrm{~min}$ in PBS-NS with a fluorescein-labeled goat anti-rabbit IgG serum (Vector Laboratories, Burlingame, CA). Finally, the cells were rinsed $3 x$ in PBS and mounted in 50\% glycerol in PBS.

For double staining with GFAP and GC, the coverslips were washed $3 \times$ in L- 15 medium with $10 \%$ normal horse serum and then incubated with a monoclonal $\mathrm{GC}$ antibody for $30 \mathrm{~min}$ at $37^{\circ} \mathrm{C}$ in $3 \% \mathrm{CO}_{2}$. Cells were gently rinsed in L-15 medium, and, after washing in PBS, rhodamine-conjugated anti-mouse immunoglobulins (IgA, IgG, and IgM) were applied in a 1:25 dilution for $30 \mathrm{~min}$. Cultures were then rinsed in PBS for $5 \mathrm{~min}$ and fixed in cold acetone, rinsed in PBS, and stained for the intracellular antigen. The coverslips were mounted in $50 \%$ glycerol in PBS.

In order to determine if neurons were present in our cultures, cultures were fixed in cold acetone for $5 \mathrm{~min}$ and washed in PBS; they were then labeled with primary anti-neurofilament antibody at a 1:2000 dilution followed by biotinylated goat anti-rabbit IgG. After washing, cultures were incubated for $30 \mathrm{~min}$ in avidin-biotin complex and then visualized using diaminobenzidine.

\section{Results}

\section{Astrocytes and other cell types in culture}

Although primary cultures from neonatal rat forebrain are heterogeneous in composition and contain cells such as astrocytes, oligodendrocytes, fibroblasts, microglia, and ependymal cells, all published studies have concluded that the majority of the cells (>90-95\%) are astrocytes (Abney et al., 1981; Fedoroff, 1986; Goldman et al., 1986). In addition, the vast majority of neurons do not survive the initial plating or the conditions of culturing that do not promote neuronal outgrowth (i.e., high serum concentrations and lack of mitotic inhibitors in the culture media; Bottenstein, 1985). Of concern in our studies on the maturation of the $\mathrm{Na}$ channel in astrocytes was the presence 
of nonastrocytic cells, which would either interfere with or dilute the neurotoxin-stimulated $\mathrm{Na}^{+}$influx or the specific binding of ${ }^{3} \mathrm{H}$-STX. To determine the cell types present in our cultures, we used cell type-specific markers: (1) GFAP, an astrocyte marker; (2) neurofilament, a neuronal marker; and (3) GC, an oligodendrocyte marker. Two types of primary astrocyte cultures were studied: (1) those maintained in serum-containing medium, and (2) those maintained in serum-free medium. We did not find neurons in any of our cultures. Early astrocytes were flat polygonal cells that display a cytoplasmic pattern of GFAP staining (Fig. $1 A$ ). Older astrocytes, both in primary culture and in chemically defined medium, were stellate and demonstrated a more intense staining pattern in their processes (Fig. 1, $B, C$ ).

$\mathrm{GFAP}^{+}$cells comprised $>94 \%$ of the primary cultures. The major nonastrocytic cell was the oligodendrocyte. $\mathrm{GC}^{+}$cells ranged from 3.5 to $5.9 \%$ after $2-3$ weeks in serum-containing medium and grew on top of the astrocytes. These small processbearing $\mathrm{GC}^{+}$cells were $\mathrm{GFAP}^{-}$. A greater proportion of oligodendrocytes was present in 3-week-old cultures in chemically defined medium (11\%). Fibroblasts were found occasionally in the cultures, as groups of cells strung end to end. Munson et al. (1979) described neurotoxin-stimulated Na channels in fibroblasts and found that the channels were in low density and had a low sensitivity for TTX. In preliminary experiments (data not shown), we performed ${ }^{3} \mathrm{H}-\mathrm{STX}$ binding studies on purified cultures of oligodendrocytes (Bottenstein, 1985). No specific STX binding sites were found. Similar results were found by Bevan et al. (1985) and Barres et al. (1988), who observed no voltagesensitive Na current. Thus we conclude that in our cultures, the $\mathrm{Na}$ channels that we detected were in astrocytes.

\section{Functional properties of voltage-sensitive Na channels in cortical astrocytes}

Initial studies were carried out to determine the functional properties and STX sensitivity of voltage-sensitive $\mathrm{Na}$ channels in primary cultures under conditions that have been shown to persistently and maximally activate $\mathrm{Na}$ channels in excitable cells. The rate of toxin-stimulated influx in the presence of both BTX and AxTx was linear up to $30 \mathrm{sec}$ in $10 \mathrm{~mm} \mathrm{Na}^{+}$(Fig. 2). Assay time was therefore limited to $10 \mathrm{sec}$ to measure initial rates of $\mathrm{Na}^{+}$influx. The magnitude of $\mathrm{Na}^{+}$influx within this time frame is independent of sodium pump activity because ouabain (1 mM) had no effect on the measurement of the rate of BTX + AxTx-stimulated $\mathrm{Na}^{+}$influx (not shown).

BTX + AxTx-stimulated $\mathrm{Na}^{+}$influx was detectable at all times in culture (Fig. 3). It was most variable in 1-week-old cultures $(0.23 \pm 0.05 \mathrm{nmol} / \mathrm{mg}$ protein $/ \mathrm{sec})$. The influx peaked at 2 weeks in culture $(0.43 \pm 0.02 \mathrm{nmol} / \mathrm{mg}$ protein $/ \mathrm{sec})$ and
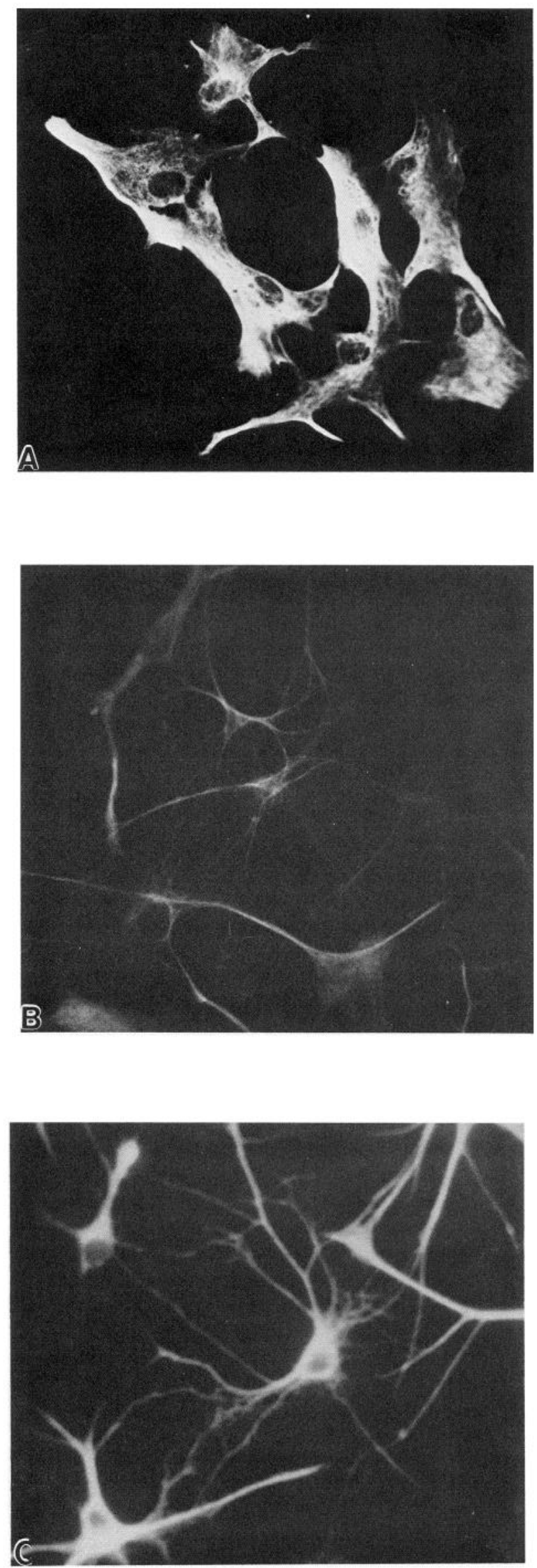

Figure 1. Morphological changes in astrocytes with time in culture and culture conditions. $A$, Photomicrograph of 9-d-old primary culture of astrocytes maintained in serum containing medium immunostained with rabbit anti-cow GFAP serum (1:500 dilution). $\times 100$. Bound antibody was detected with goat anti-rabbit IgG coupled to fluorescein. Note the large somata and limited processes. $B$, Fluorescent photomicrograph of 14-d-old culture in serum containing medium stained with GFAP. $\times 100$. The filamentous pattern of staining is present. $C$, Fluorescent micrograph of 13-d-old chemically defined medium stained with GFAP. The cells show a small somata and multiple processes. $\times 100$. 


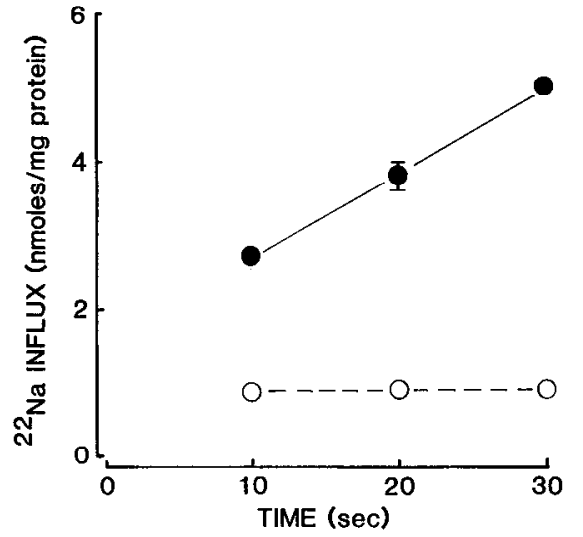

Figure 2. Time dependence of $\mathrm{Na}^{+}$influx in cultured astrocytes. Cells at $18 \mathrm{~d}$ in culture were preincubated in $\mathrm{Na}^{+}$-free medium in the absence (O) or in the presence (0) of $1 \mu \mathrm{M}$ BTX $+100 \mathrm{~nm} \mathrm{AxTx}$ at $35^{\circ} \mathrm{C}$. After $30 \mathrm{~min}$, the medium was removed and influx was measured in a low$\mathrm{Na}^{+}\left(10 \mathrm{~mm} \mathrm{Na}{ }^{+}\right)$solution. Control influx did not increase during 10 $30 \mathrm{sec}$. Data are uncorrected for zero time influx. Values are means of 4 determinations. Error bars show $\pm \mathrm{SE}$ when larger than the dimension of the symbol. Linear regression lines are shown.

then declined by $45 \%$ at 3 weeks to $0.23 \pm 0.02$, where it remained up to at least 4 weeks (Fig. 3). Unstimulated rates of $\mathrm{Na}^{+}$influx did not change with time in culture (mean value 80 $\mathrm{pmol} / \mathrm{mg}$ protein $/ \mathrm{sec}$ ). By 2 weeks, the cultures were approaching confluence and morphological changes were evident.

\section{Two types of functional Na channels in cortical astrocytes}

TTX and STX have been widely used as probes for voltagegated $\mathrm{Na}$ channels in electrically excitable tissues and in isolated membranes. Both toxin-sensitive and toxin-insensitive $\mathrm{Na}$ channels have been described, and these channels have similar affinities for BTX and veratridine. Figure 3 shows the profile of inhibition of neurotoxin-stimulated ${ }^{22} \mathrm{Na}^{+}$influx by STX at $35^{\circ} \mathrm{C}$ in astrocytes after either $7 \mathrm{~d}$ or $14 \mathrm{~d}$ in standard culture conditions (serum-containing medium). In 7-d-old cultures containing predominantly flat cells, a single, low-affinity Na channel population with an apparent $\mathrm{K}_{\mathrm{i}(\mathrm{STX})}$ of $167 \mathrm{nM}$ was present (Fig. $4 A$ ). This inhibition curve was analyzed assuming that the interaction of STX with each of the putative binding sites obeys the laws of mass action (Haimovich et al., 1986). Nonlinear least squares analysis indicated that the data were best fit using a 1-site model.

In 14-d-old and older cultures containing predominantly stellate cells, STX inhibition of ${ }^{22} \mathrm{Na}^{+}$influx showed a more complex form than in younger cultures. STX inhibited ${ }^{22} \mathrm{Na}^{+}$influx at concentrations that were ineffective in 7-d-old cultures. Highaffinity and low-affinity sites were detected with apparent $\mathrm{K}_{\mathrm{i}}$ values of $0.2 \mathrm{~nm}$ and $153 \mathrm{~nm}$, respectively (Fig. $4 B$ ). The fraction of high-affinity $\left(\mathrm{F}_{\mathrm{H}}\right)$ and low-affinity $\left(\mathrm{F}_{\mathrm{L}}\right)$ sites was $39 \%$ and $62 \%$, respectively. This inhibition curve was fit to both 1 -site and multisite models. The 2 -sitc modcl was a significant improvement over the 1 -site model ( $p<0.01$ ), and a 3 -site model gave no further improvement. The differences in STX sensitivity between young ( $\leq 7 \mathrm{~d}$ ) and older ( $\geq 12 \mathrm{~d}$ ) cultures suggested that the population of voltage-gated $\mathrm{Na}$ channels in astrocytes changed with time in culture, with channels with high affinity for STX appearing in older cultures.

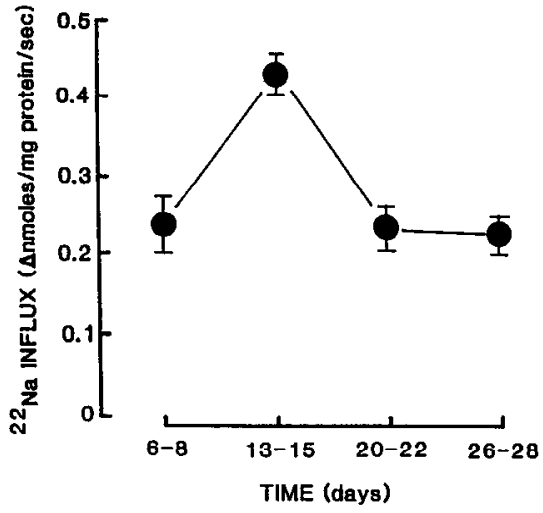

Figure 3. Time course of neurotoxin-stimulated $\mathrm{Na}^{+}$influx in primary cultures of astrocytes. Neurotoxin-stimulated $\mathrm{Na}^{+}$influx was measurable through 4 weeks. Flux was measured in the presence of $1 \mu \mathrm{M}$ BTX $+100 \mathrm{~nm}$ AxTx. Values are means $\pm \mathrm{SE}$. Error bars indicate $\pm \mathrm{SE}$ for at least 4 experiments.

\section{High- and low-affinity STX binding}

Our studies of the inhibition of ${ }^{22} \mathrm{Na}^{+}$influx by STX indicated that older astrocytes contained $\mathrm{Na}$ channels with 2 different affinities for STX. Two populations were also revealed by measurements of ${ }^{3} \mathrm{H}-\mathrm{STX}$ binding in astrocyte membranes. Astrocyte membranes were prepared from 14- to 20-d-old primary serum-containing cultures. Specific STX binding was saturable with a complex form suggesting multiple sites (Fig. 5). A Scatchard plot (Fig. $5 B$ ) of the equilibrium binding corrected for nonspecific binding demonstrated that the astrocytes contained 2 populations of STX receptor sites with a $K_{d}$ of $0.12-0.31 \mathrm{nM}$ and a $B_{\max }$ of $0.4-1.2 \mathrm{pmol} / \mathrm{mg}$ protein and a second site with a $K_{d}$ of $10-20 \mathrm{nM}$ and a $B_{\max }$ of $1.5-3 \mathrm{pmol} / \mathrm{mg}$ protein. This 2 -site fit was significantly better than a 1 -site model $(F=9.3$; $p<0.02)$ using the LIGAND program of Munson and Rodbard (1980). The computer-generated saturation curve (Fig. $5 \mathrm{~A}$ ) consists of 3 components, 2 saturable specific components and a linear nonspecific component. The Scatchard plot (Fig. 5B) of specific STX binding was nonlinear and was well fit as the sum of 2 separate populations of binding sites (Mais et al., 1974).

\section{Induction of high-affinity STX binding in serum-free medium}

The apparent $\mathrm{K}_{\mathrm{i}}$ values obtained for the high-affinity site (Fig. $4 B$ ) from 2-week-old serum-containing cultures were quite variable $(0.2-10 \mathrm{~nm})$, possibly due to the variable state of maturation of the cultures. Cultures at this stage consist of both rapidly dividing, flat cells and more slowly dividing, stellate cells. In order to examine the possibility that it is the stellate cells that have high-affinity STX channels, we used chemically defined medium in place of our regular culture medium (MEM $+10 \%$ FCS). This medium, G5 (Bottenstein, 1985), induced a morphological change in the astrocytes from flat to stellate morphology. This effect was rapid; nearly all cells underwent the change in morphology within $15 \mathrm{hr}$. After $4 \mathrm{~d}$ in chemically defined medium, beginning at day 7 , the inhibition curve was similar in shape to 14-d-old primary cultures and was less variable among different cultures. It remained biphasic up to 3 weeks, with $\mathrm{K}_{\mathrm{i}}$ s of $0.3 \mathrm{~nm}$ and $300 \mathrm{~nm}$ (Fig. 6). There was a higher proportion of high-affinity sites in chemically defined cultures $\left(\mathrm{F}_{\mathrm{H}}, 62 \%\right)$ than was found in 14-d-old primary serumcontaining cultures (see above). 


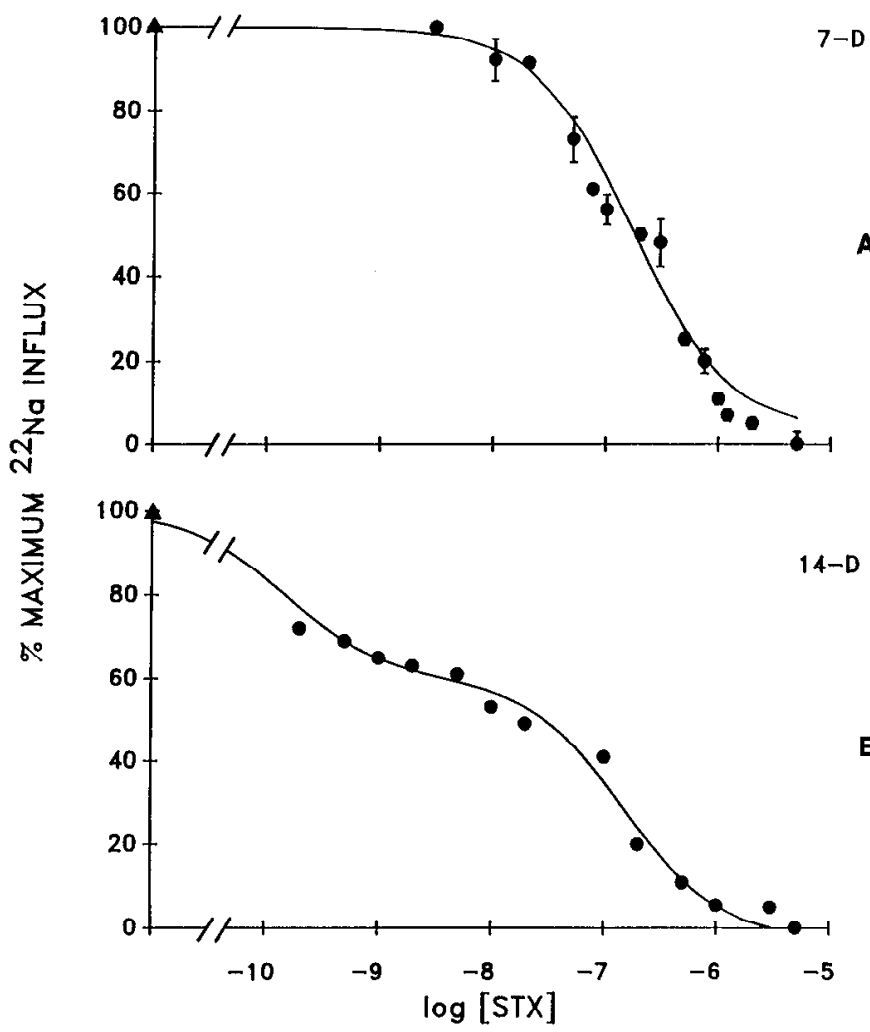

Figure 4. Inhibition of neurotoxin-activated $\mathrm{Na}^{+}$influx by STX changes with culture maturation. $A$, Inhibition curve in 7-d-old cultures in serum-containing medium $(n=3)$ was fitted by a single-site model with a $\mathrm{K}_{\mathrm{i}}$ of $167 \mathrm{nM}$. B. Blockade of BTX-stimulated Na influx by STX at $14 \mathrm{~d}$ in culture was best fit by a two-site model with $\mathrm{K}_{\mathrm{i}}$ 's of $0.2 \mathrm{nM}$ and $153 \mathrm{nM}$. The BTX + AxTx-stimulated $\mathrm{Na}^{+}$influx in the absence of STX is indicated $(\triangle)$. Values are means \pm SE.

\section{Time course of high-affinity STX binding}

To determine the time course of appearance of high-affinity STX binding sites, we measured cell binding of ${ }^{3} \mathrm{H}-\mathrm{STX}$ daily from day 7 to day 12 in cultures maintained in the presence or absence of serum (Fig. 7). Binding was measured at $5 \mathrm{nM}$, a concentration of STX at which all the high-affinity STX sites and $25 \%$ of the low-affinity sites are saturated at $4^{\circ} \mathrm{C}$. Under standard culture conditions, binding was unchanged at 7 and $8 \mathrm{~d}(0.3 \mathrm{pmol} / \mathrm{mg}$ protein) and reflected all low-affinity sites (Fig. 4A). High-affinity sites began to increase at day 9 . Between 9 and $11 \mathrm{~d}$, a very rapid increase in the numbers of high-affinity binding sites occurred that continued between days 11 and $14(2.2 \mathrm{pmol} / \mathrm{mg}$ protein at $14 \mathrm{~d}$ ). This increase in specific binding reached a maximum at 2 weeks in culture and was maintained for at least 2 weeks longer.

Switching cultures to G5 medium induced a different time course in the appearance of high-affinity STX binding from that in serum-containing medium. After placing cultures in $\mathrm{B} 5 \mathrm{me}$ dia at day 7 , there was a rapid increase overnight in the number of high STX affinity $\mathrm{Na}$ channels $(2.5 \mathrm{pmol} / \mathrm{mg}$ protein). This increase in toxin-sensitive $\mathrm{Na}$ channels occurred at a time when most of the STX binding sites were of low affinity in standard medium (Fig. 4A). A further increase in the number of highaffinity $\mathrm{Na}$ channels was observed in these chemically defined cultures at day 10 ( $4 \mathrm{pmol} / \mathrm{mg}$ protein), and this level of specific binding was maintained at day 11 .
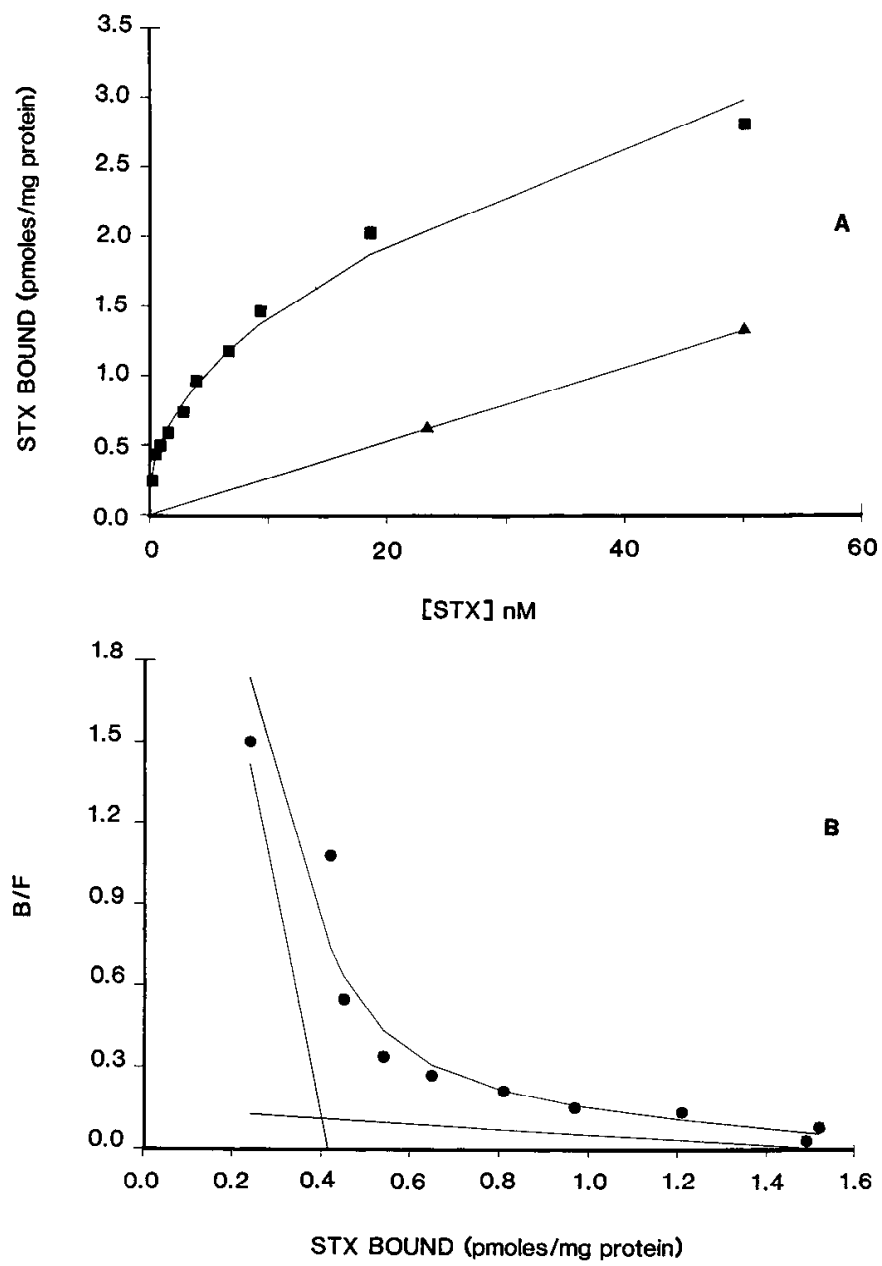

Figure 5. Binding of ${ }^{3} \mathrm{H}-\mathrm{STX}$ to plasma membranes prepared from 14-d-old astrocyte cultures. Plasma membranes from cultures were incubated in various concentrations of ${ }^{3} \mathrm{H}-\mathrm{STX}+5 \mu \mathrm{M}$ cold STX at $4^{\circ} \mathrm{C}$. $A$, Total binding was fit by a saturation curve consisting of 3 components with 2 saturable specific components and a linear nonspecific component (A). B, Scatchard analysis of specific STX binding. The curve was fit by an equation with 2 specific sites. The high-affinity site for STX had a $\mathrm{K}_{d}$ of $0.12 \mathrm{nM}$ and a low-affinity site had a $\mathrm{K}_{\mathrm{d}}$ of $10 \mathrm{nM}$.

\section{Discussion}

Low and high STX affinity $\mathrm{Na}$ channels in cultured astrocytes A spontaneous, progressive change in the affinity of astrocyte $\mathrm{Na}$ channels for STX has been demonstrated by both our tracer flux and binding studies. This change was due to the appearance of high-affinity STX channels beginning at day 8 (Fig. 7). Lowaffinity $\mathrm{Na}$ channels were continuously present through the 4 th week in culture. At $7 \mathrm{~d}$ in culture the low-affinity comprised $>90-95 \%$ of the channels, and at $14 \mathrm{~d}$ they constituted $60 \%$ of total Na channel sites (Fig. 4).

These results may provide an explanation for previous observations. Bevan et al. (1985) reported that the TTX sensitivity of the whole-cell $\mathrm{Na}$ current in rat cortical astrocytes was low, with $520 \mathrm{nM}$ TTX required to block half the Na current, even though high-affinity sites $\left(\mathrm{K}_{\mathrm{d}}=2 \mathrm{nM}\right)$ were revealed with ${ }^{3} \mathrm{H}$ STX binding. Although no reference to the age of the cultures was given, this result together with their values of $B_{\max }$, at least 8 -fold less than ours at $14 \mathrm{~d}$, suggests that they may have been using young cultures with predominantly toxin-insensitive channels. 


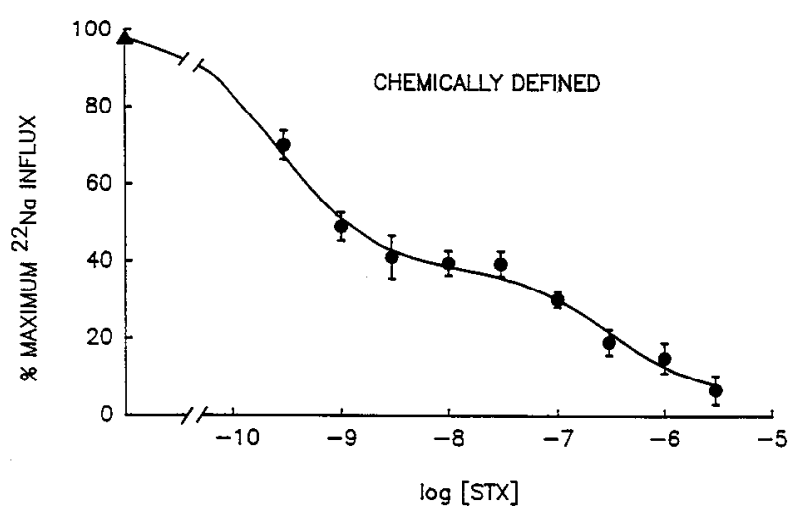

Figure 6. Serum-free medium induces expression of high STX affinity Na channel. Young primary cultures were changed to serum-free chemically defined medium (G5) at day 7. STX inhibition of $\mathrm{Na}$ influx was measured later at $22 \mathrm{~d}(n=3)$. The inhibition by STX of neurotoxinstimulated ${ }^{22} \mathrm{Na}^{+}$influx was best fit by a 2-site model with the highaffinity $\mathrm{K}_{\mathrm{i}}$ of $0.27 \mathrm{nM}$ and low-affinity $\mathrm{K}_{\mathrm{i}}$ of $304 \mathrm{~nm}$. The BTX + AxTxstimulated ${ }^{22} \mathrm{Na}^{+}$influx in the absence of STX is indicated $(\Delta)$. Values are means $\pm \mathrm{SE}$

Despite the fact that the proportion of the 2 subtypes of $\mathrm{Na}$ channels changed with astrocyte development in vitro, the magnitude of the BTX-stimulated ${ }^{22} \mathrm{Na}^{+}$influx remained quite substantial throughout 4 weeks in culture. There was, however, a transient increase in $\mathrm{Na}^{+}$influx coincident with the rapid rise in high-affinity STX binding (Figs. 3, 7). This rise and fall of $\mathrm{Na}^{+}$influx may indicate a coordinated up-regulation of highaffinity STX Na channels and a down-regulation of low-affinity $\mathrm{Na}$ channels. In general, our results are similar to observations in cultures of other electrically excitable cells that have both Na-channel subtypes, such as skeletal muscle cells (Sherman et al., 1983; Haimovich et al., 1986) or cardiac cells (Renaud et al., 1983). In both of these cell types, the magnitude of site 2-stimulated $\mathrm{Na}^{+}$influx is independent of the STX or TTX affinity of $\mathrm{Na}$ channels. Thus it appears that as much $\mathrm{Na}$ flows through the STX-insensitive Na channels as through the STXsensitive $\mathrm{Na}$ channels and that the levels of BTX + AxTxstimulated ${ }^{22} \mathrm{Na}^{+}$influx do not reveal which type of channel is present.

\section{Differential development of Na channel subtypes}

The changes in expression of $\mathrm{Na}$-channel subtypes in astrocytes were similar to those reported for cultured cardiac cells and ventricular muscle in vivo (Renaud et al., 1983) and cultured rat skeletal muscle (Frelin et al., 1983; Sherman et al., 1983; Haimovich et al., 1986). In young cultures of astrocytes, STX blocked neurotoxin-stimulated $\mathrm{Na}$ influx with a $\mathrm{K}_{0.5}$ comparable to that found in toxin-insensitive channels in myoblasts (astrocytes, $\mathrm{K}_{0.5}=160 \mathrm{~nm} \mathrm{STX}$ at $35^{\circ} \mathrm{C} ;$ myoblasts, $\mathrm{K}_{0.5}=135 \mathrm{nM}$ TTX; Renaud et al., 1983). In older cultured astrocytes, toxinsensitive channels had similar dissociation constants for both STX blockade of BTX-activated influx $\left(\mathrm{K}_{0.5}\right)$ and labeled STX binding.

In cardiac cells, toxin-insensitive $\mathrm{Na}$ channels are present before birth, and toxin-sensitive channels appear at $5 \mathrm{~d}$ of postnatal life. The density of high-affinity $\mathrm{Na}$ channels increases and reaches a maximum at $45 \mathrm{~d}$ in culture. $\mathrm{Na}$ channels in mammalian skeletal muscle cells also undergo large overall shifts in TTX sensitivity during muscle development. In early stages a TTX-insensitive channel type is predominant in myoblasts; as

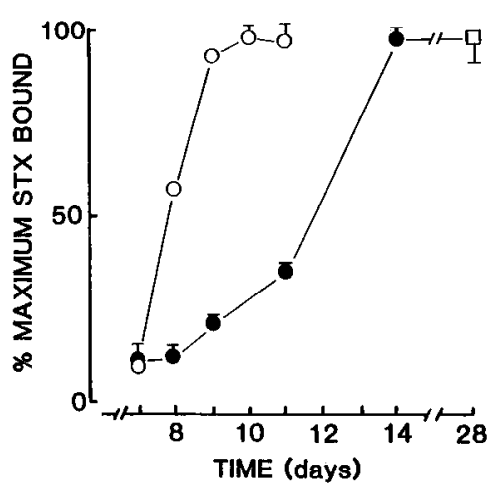

Figure 7. Time course of high STX affinity binding in astrocyte cultures in different culture conditions. Specific binding of ${ }^{3} \mathrm{H}$-STX was measured in cultures of astrocytes for 4 weeks. Nonspecific binding in $5 \mu \mathrm{M}$ STX was subtracted. In primary cultures $(\bullet)$ from 9-14 d there was a sustained increase in specific binding (day $7,0.3 \mathrm{pmol} / \mathrm{mg}$ protein). Binding reached a maximum ( $2 \mathrm{pmol} / \mathrm{mg}$ protein) after $14 \mathrm{~d}$ in culture and was maintained for 2 more weeks ( $\square$ ). In cultures placed in G5 medium at day $7(0)$, there was a much faster increase in high STX affinity binding, which reached a maximum by day $10(4.3 \mathrm{pmol} / \mathrm{mg}$ protein). Error bars show standard errors of 3 groups of matched cultures between $7 \mathrm{~d}$ and $14 \mathrm{~d}$ and of at least 4 different cultures between $14 \mathrm{~d}$ and $24 \mathrm{~d}$.

the mononuclear cells begin to fuse, TTX-sensitive channels supplant the TTX-resistant channels in myotubes (Sherman et al., 1983; Haimovich et al., 1986). Using patch-clamp techniques, Weiss and Horn (1986) demonstrated that the 2 channel subtypes were present in the same cell. Moreover, TTX-insensitive channels had a lower single-channel conductance, were less sensitive to block by $\mathrm{Ca}^{2+}$, and could be activated at more hyperpolarized voltages than TTX-sensitive channels.

\section{Manipulation of Na channel subtypes in astrocytes}

From our results, it cannot be determined whether stellate and polymorphic cells (which coexist in older cultures because of unsynchronized development) both have the same channel types. We considered the possibility that the different $\mathrm{Na}$ channel subtypes might be associated witih astrocytes of distinct morphologies, i.e., that high-affinity channels were found only on "mature" stellate cells, whereas low STX affinity channels were located on immature polymorphic cells. One way that the normal spontaneous change in astrocyte morphology could be induced was by replacing the medium with chemically defined media (Bottenstein, 1985). We found that after changing to G5 medium at day 7 all the astrocytes changed within $15 \mathrm{hr}$ from flat cells with few processes to stellate cells with multiple processes (Fig. 1).

Changing cultures to chemically defined media (G5) at day 7 also induced a sizable increase in the number of high-affinity STX channels per cell by day $8\left(1.2 \times 10^{5}\right.$ sites/cell). Lowaffinity channels were still present in these cultures, and thus both $\mathrm{Na}$ channel subtypes were present on stellate cells. It is not known where $\mathrm{Na}$ channels are located on the membrane of the astrocyte. One suggestion is that the 2 channel types are spatially separate, with high-affinity $\mathrm{Na}$ channels on the astroglial processes and low-affinity $\mathrm{Na}$ channels on the astrocyte somata. The proportion of channel subtypes in these treated cultures was different from that found in older standard cultures. Based on a block of $\mathrm{Na}^{+}$influx, more than $60 \%(62.2 \pm 1.1 \%$; mean $\pm \mathrm{SE} ; n=3$ ) are high-affinity channels, compared to about $40 \%$ $(39.1 \pm 2.3 \%)$ in primary cultures. 
There is a precedent for culture conditions influencing regulation of $\mathrm{Na}$ channel density in cell lines of neuronal origin. In neuroblastoma (N1E115) and pheochromocytoma (PC12), morphological differentiation (process extension) in the presence of DMSO or nerve growth factor occurs concomitantly with increases in the numbers of $\mathrm{Na}$ channels with high affinity for STX or TTX (Rudy et al., 1982, 1987; Baumgold and Spector, 1987). However, unlike the spontaneous changes in the affinity of the Na channel for STX reported here for astrocytes, these increases in the numbers of $\mathrm{Na}$ channels in neuroblastoma and pheochromocytoma cell lines must be induced by addition of active substances to the medium.

The mechanism responsible for the spontaneous increase in the numbers of high-affinity $\mathrm{Na}$ channels is not known. Transcriptional regulation of a second gene, alternate splicing mechanisms, or post-translational modification of the toxin-insensitive channel protein could all account for a different type of functional $\mathrm{Na}$ channel (cf. Noda et al., 1986; Mandel et al., 1988). This spontaneous process can be greatly accelerated by conditions that promote the change from immature polygonal astrocytes to the mature stellate form, such as switching to G5 medium. Ilowever, the conversion is incomplete, and both high and low STX affinity channels are present in the older stellate astrocytes in both serum-containing and serum-free media. Because the appearance of high-affinity $\mathrm{Na}$ channels in astrocytes may be correlated with medium change, we are currently investigating other stimuli such as neuronal-glial contact and/or release of gliotrophic substances (Hatten, 1987) for their ability to induce high-affinity $\mathrm{Na}$ channels.

\section{References}

Abney, E. R., P. P. Bartlett, and M. C. Raff (1981) Astrocytes, ependymal cells, and oligodendrocytes develop on schedule in dissociated cell cultures of embryonic rat brain. Dev. Biol. 83: 301-310.

Barres, B. A., L. L. Y. Chun, and D. P. Corey (1988) Ion channel expression by white matter glia: I. Type 2 astrocytes and oligodendrocytes. Glia $1: 10-30$.

Baumgold, J., and I. Spector (1987) Development of sodium channel protein during chemically induced differentiation of neuroblastoma cells. J. Neurochem 48: 1264-1269.

Bevan, S., S. Y. Chiu, P. T. A. Gray, and J. M. Ritchie (1985) The presence of voltage-gated sodium, potassium and chloride channels in rat cultured astrocytes. Proc. R. Soc. Lond. [Biol.] 225: 299-313.

Booher, J., and M. Sensenbrenner (1972) Growth and cultivation of dissociated ncurons and glial cells from embryonic chick, rat and human brain in flask cultures. Neurobiology 2: 97-105.

Bottenstein, J. E. (1985) Growth and differentiation of neural cells in defined media. In Cell Culture in the Neurosciences, J. E. Bottenstein and G. Sato, eds., pp. 3-43, Plenum, New York.

Bowman, C. L., H. K. Kimelberg, M. V. Frangakis, Y. Berwald-Netter, and C. Edwards (1984) Astrocytes in primary culture have chemically activated sodium channels. J. Neurosci. 4: 1527-1534.

Catterall, W. A. (1981) Studies of voltage-sensitive sodium channels in cultured cells using ion-flux and ligand-binding methods. In $E x$ citable Cells in Tissue Culture, P. G. Nelson and M. Lieberman eds., pp. 279-317, Plenum, New York.

Catterall, W. A. (1986) Molecular properties of voltage-sensitive sodium channels. Annu. Rev. Biochem. 55: 953-985.

Fcdoroff, S. (1986) Prenatal ontogenesis of astrocytes. In Astrocytes, Vol. 1, S. Fedoroff and A. Vernadakis, eds., pp. 30-70, Academic, Orlando, FL.

Frelin, C., P. Vigne, and M. Lazdunski (1983) $\mathrm{Na}^{+}$channels with high and low affinity tetrodotoxin binding sites in the mammalian skeletal muscle cell. Difference in functional properties and sequential appearance during rat skeletal myogenesis. J. Biol. Chem. 258: 72567259.

Goldman, J. E., S. S. Geier, and M. Hirano (1986) Differentiation of astrocytes and oligodendrocytes from germinal matrix cells in primary culture. J. Neurosci. 6: 52-60.
Gray, P. T. A., and J. M. Ritchie (1986) A voltage-gated chloride conductance in rat cultured astrocytes. Proc. R. Soc. Lond. [Biol.] 228: 267-288.

Haimovich, B., J. C. Tanaka, and R. L. Barchi (1986) Developmental appearance of sodium channel subtypes in rat skeletal muscle cultures. J. Neurochem. 47: 1148-1153.

Hatten, M. E. (1987) Neuronal inhibition of astroglial proliferation is membrane mediated. J. Cell Biol. 104: 1353-1360.

Krueger, B. K., R. W. Ratzlaff, G. R. Strichartz, and M. P. Blaustein (1979) Saxitoxin binding to synaptosomes, membranes, and solubilized binding sites from rat brain. J. Membrane Biol. 50: 287-310.

Mais, R. F., S. Kerestes-Nagy, J. F. Zaaroslinski, and Y. T. Oester (1974) Interpretation of protein-drug interaction through fraction bound and relative contribution of secondary sites. J. Pharm. Sci. 63: $1423-1427$.

Mandel, G., S. S. Cooperman, R. A. Maue, R. H. Goodman, and P. Brehm (1988) Selective induction of brain type II Na ${ }^{+}$channels by nerve growth factor. Proc. Natl. Acad. Sci. USA 85: 924-928.

Morrison, R. S., and J. de Vellis (1984) Growth and differentiation of purified astrocytes in a chemically defined medium. In Cell Culture Methods for Molecular and Cellular Biology, Vol. 4, D. W. Barnes, D. Sireasky, and G. Sato, eds., pp. 973-985, Plenum, New York.

Munson, P. J., and D. Rodbard (1980) LIGAND: A versatile computerized approach for characterization of ligand-binding systems. Anal. Biochem. 107: 220-239.

Munson, R., Jr., B. Westermark, and L. Glaser (1979) Tetrodotoxinsensitive sodium channels in normal human fibroblasts and normal human glia-like cells. Proc. Natl. Acad. Sci. USA 76: 6425-6429.

Noda, M., T. Ikeda, H. Susuzki, H. Takeshima, T. Takahashi, M. Kuno, and S. Numa (1986) Expression of functional sodium channels from cloned cDNA. Nature 322: 826-828.

Norton, T. R., S. Shibata, M. Kashiwagi, and J. Bentley (1976) Isolation and characterization of the cardiotonic polypeptide anthopleurin-A from the sea anemone Anthopleura xanthogrammica. J. Pharm. Sci. 65: 1368-1374.

Nowak, L., P. Ascher, and Y. Berwald-Netter (1987) Ionic channels in mouse astrocytes in culture. J. Neurosci. 7: 101-109.

Pierce, J., and C. H. Suelter (1977) An evaluation of coomassie brillant blue G-250 dye-binding method for quantitative protein determination. Anal. Biochem. 81: 478-480.

Quandt, F. N., and B. A. MacVicar (1986) Calcium activated potassium channels in cultured astrocytes. Neuroscience 19: 29-41.

Ranscht, B., P. A. Clapshaw, J. Price, M. Noble, and W. Seifert (1982) Development of oligodendrocytes and Schwann cells studied with a monoclonal antibody against galactocerebroside. Proc. Natl. Acad. Sci. USA 79: 2709-2713.

Ransom, B. R., and W. G. Carlini (1986) Electrophysiological properties of astrocytes. In Astrocytes, Vol. 2, S. Fedoroff and A. Vernadakis, eds., pp. 1-49, Academic, Orlando, FL.

Renaud, J.-F., T. Kazazoglou, A. Lombet, R. Chicheportiche, E. Jaimovich, G. Romey, and M. Lazdunski (1983) The $\mathrm{Na}^{+}$channel in mammalian cardiac cells. J. Biol. Chem. 258: 8799-8805.

Ritchie, J. M., and R. B. Rogart (1977) The binding of saxitoxin and tetrodotoxin to excitable tissue. Rev. Physiol. Biochem. Pharmacol. 79: $1-50$.

Rogart, R. B., and L. J. Regan (1985) Two subtypes of sodium channel with tetrodotoxin sensitivity and insensitivity detected in denervated mammalian skeletal muscle. Brain Res. 329: 314-318.

Rudy, B., B. Kirschenbaum, and L. A. Greene (1982) Nerve growth factor-induced increase in saxitoxin binding to rat PC12 pheochromocytoma cells. J. Neurosci. 2: 1405-1411.

Rudy, B., B. Kirschenbaum, A. Rukenstein, and L. A. Greene (1987) Nerve growth factor increases the number of functional $\mathrm{Na}$ channels and induces TTX-resistant Na channels in PC12 pheochromocytoma cells. J. Neurosci. 7: 1613-1625.

Shea, T. B., I. Fischer, and V. Sapirstein (1986) Expression of a plasma membrane proteolipid during differentiation of neuronal and glial cells in primary culture. J. Neurochem. 47: 697-706.

Sherman, S. J., J. C. Lawrence, D. J. Messner, K. Jacoby, and W. A. Catterall (1983) Tetrodotoxin-sensitive sodium channels in rat muscle cells developing in vitro. J. Biol. Chem. 258: 2488-2495.

Weiss, R. E., and R. Horn (1986) Functional differences between two classes of sodium channels in developing rat skeletal muscle. Science 233: 361-364. 